\title{
Detailed North-South Cross Section Showing Environments of Deposition, Organic Richness, and Thermal Maturities of Lower Tertiary Rocks in the Uinta Basin, Utah
}

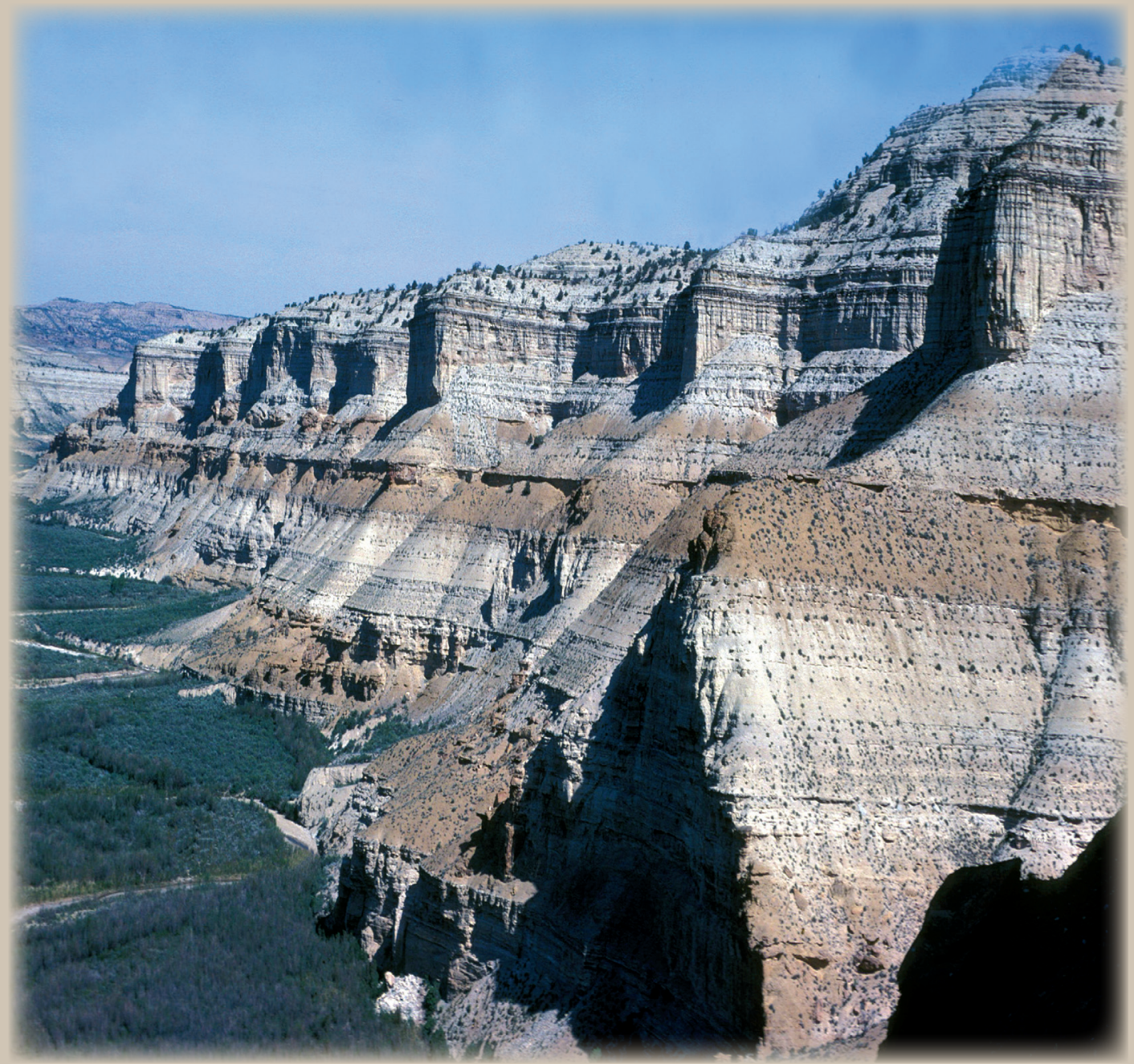

Pamphlet to accompany

Scientific Investigations Map 3304

U.S. Department of the Interior

U.S. Geological Survey 
COVER. Evacuation Creek, Uinta Basin, northeastern Utah. Photograph by R.C. Johnson, USGS, 1981. 


\section{Detailed North-South Cross Section Showing Environments of Deposition, Organic Richness, and Thermal Maturities of Lower Tertiary Rocks in the Uinta Basin, Utah}

By Ronald C. Johnson

Pamphlet to accompany

Scientific Investigations Map 3304 


\title{
U.S. Department of the Interior SALLY JEWELL, Secretary
}

\section{U.S. Geological Survey Suzette M. Kimball, Acting Director}

\author{
U.S. Geological Survey, Reston, Virginia: 2014
}

For more information on the USGS - the Federal source for science about the Earth, its natural and living resources, natural hazards, and the environment, visit http://www.usgs.gov or call 1-888-ASK-USGS.

For an overview of USGS information products, including maps, imagery, and publications, visit http://www.usgs.gov/pubprod

To order this and other USGS information products, visit http://store.usgs.gov

Any use of trade, firm, or product names is for descriptive purposes only and does not imply endorsement by the U.S. Government.

Although this information product, for the most part, is in the public domain, it also may contain copyrighted materials as noted in the text. Permission to reproduce copyrighted items must be secured from the copyright owner.

Suggested citation:

Johnson, R.C., Detailed north-south cross section showing environments of deposition, organic richness, and thermal maturities of lower Tertiary rocks in the Uinta Basin, Utah: U.S. Geological Survey Scientific Investigations Map 3304, 12 p., 1 sheet, $h t t p: / / d x$. doi.org/10.3133/sim3304. 


\section{Contents}

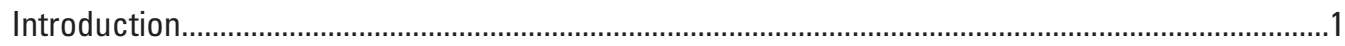

Stratigraphic Subdivisions of the Green River Formation...............................................................

Variations in Thermal Maturity Using Rock-Eval and Vitrinite Reflectance .................................... 7

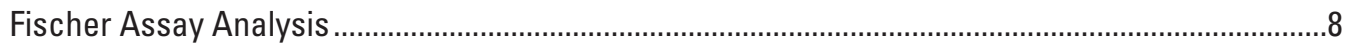

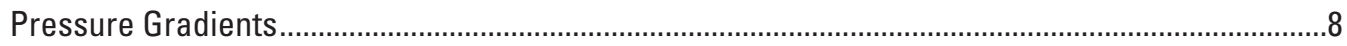

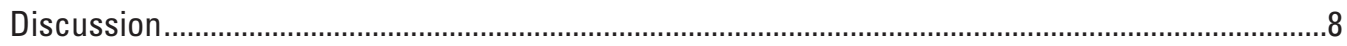

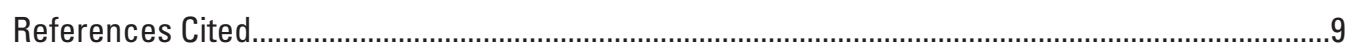

\section{Figures}

1. Map showing extent of Uinta, Piceance, and Greater Green River Basins, and the approximate extent of oil shale in the Green River Formation.

2. West-east cross section across the Uinta Basin, the Douglas Creek arch, and the Piceance Basin showing stratigraphic subdivisions, lithologies and variations in thermal maturity measured using vitrinite reflectance.

3. Index map showing detailed cross sections of Upper Cretaceous and lower Tertiary rocks published by the U.S. Geological Survey in the Uinta and Piceance Basins ...........5

4. Cross section showing oil-yield histograms, members of the Eocene Green River Formation, correlation of rich- and lean-oil shale zones of Cashion and Donnell (1972), and stages in the evolution of Lake Uinta

\section{Sheet}

1. Detailed North-South Cross Section Showing Environments of Deposition, Organic Richness, and Thermal Maturities of Lower Tertiary Rocks in the Uinta Basin,

Utah 


\section{Conversion Factors}

\begin{tabular}{|c|c|c|}
\hline Multiply & By & To obtain \\
\hline \multicolumn{3}{|c|}{ Length } \\
\hline foot $(\mathrm{ft})$ & 0.3048 & meter $(\mathrm{m})$ \\
\hline mile (mi) & 1.609 & kilometer $(\mathrm{km})$ \\
\hline \multicolumn{3}{|c|}{ Volume } \\
\hline gallon (gal) & 3.785 & liter (L) \\
\hline \multicolumn{3}{|c|}{ Mass } \\
\hline ton, short $(2,000 \mathrm{lb})$ & 0.9072 & megagram (Mg) \\
\hline \multicolumn{3}{|c|}{ Pressure } \\
\hline pound per square inch $\left(\mathrm{lb} / \mathrm{in}^{2}\right)$ & 6.895 & kilopascal (kPa) \\
\hline \multicolumn{3}{|l|}{ SI to Inch/Pound } \\
\hline Multiply & By & To obtain \\
\hline \multicolumn{3}{|c|}{ Length } \\
\hline millimeter $(\mathrm{mm})$ & 0.03937 & inch (in.) \\
\hline meter $(\mathrm{m})$ & 3.281 & foot $(\mathrm{ft})$ \\
\hline kilometer $(\mathrm{km})$ & 0.6214 & mile (mi) \\
\hline \multicolumn{3}{|c|}{ Volume } \\
\hline liter (L) & 0.2642 & gallon (gal) \\
\hline \multicolumn{3}{|c|}{ Mass } \\
\hline $\operatorname{gram}(\mathrm{g})$ & 0.03527 & ounce, avoirdupois (oz) \\
\hline megagram $(\mathrm{Mg})$ & 1.102 & ton, short $(2,000 \mathrm{lb})$ \\
\hline
\end{tabular}

Altitude, as used in this report, refers to distance above the vertical datum.

Temperature in degrees Celsius $\left({ }^{\circ} \mathrm{C}\right)$ may be converted to degrees Fahrenheit $\left({ }^{\circ} \mathrm{F}\right)$ as follows:

${ }^{\circ} \mathrm{F}=\left(1.8 \times{ }^{\circ} \mathrm{C}\right)+32$

Temperature in degrees Fahrenheit $\left({ }^{\circ} \mathrm{F}\right)$ may be converted to degrees Celsius $\left({ }^{\circ} \mathrm{C}\right)$ as follows:

${ }^{\circ} \mathrm{C}=\left({ }^{\circ} \mathrm{F}-32\right) / 1.8$ 


\title{
Detailed North-South Cross Section Showing Environments of Deposition, Organic Richness, and Thermal Maturities of Lower Tertiary Rocks in the Uinta Basin, Utah
}

\author{
By Ronald C. Johnson
}

\section{Introduction}

The Uinta Basin of northeast Utah (fig. 1) has produced large amounts of hydrocarbons from lower Tertiary strata since the 1960s (Lucas and Drexler, 1976). Recent advances in drilling technologies, in particular the development of efficient methods to drill and hydraulically fracture horizontal wells, has spurred renewed interest in producing hydrocarbons from unconventional low-permeability dolomite and shale reservoirs in the lacustrine, Eocene Green River Formation. The Eocene Green River Formation was deposited in Lake Uinta, a long-lived saline lake that occupied the Uinta Basin, the Piceance Basin to the east, and the intervening Douglas Creek arch (figs. 1-3). The focus of recent drilling activity has been the informal Uteland Butte member of the Green River Formation (Osmond, 1992) and to a much lesser extent the overlying R-0 oil shale zone of the Green River Formation (figs. 2, 4). Initial production rates ranging from 500 to 1,500 barrels of oil equivalent per day have been reported from the Uteland Butte member from horizontal well intervals that are as long as 4,000 feet (ft; Durham, 2013). The cross section presented here extends northward from outcrop on the southern margin of the basin into the basin's deep trough, located just south of the Uinta Mountains, and transects the area where this unconventional oil play is developing. A major fluvial-deltaic system entered Lake Uinta from the south (Cashion, 1967), and this new line of section is ideal for studying the effect of the sediments delivered by this drainage on hydrocarbon reservoirs in the Green River Formation. The Monument Butte Oil Field, which is one of the fields located along this line of section, has produced hydrocarbons from conventional sandstone reservoirs in the lower part of the Green River Formation and underlying Wasatch Formation since 1981 (Lomax, 1993).

The cross section also transects the Greater Altamont-Bluebell field in the deepest part of the basin, where hydrocarbons have been produced from fractured, highly overpressured marginal lacustrine and fluvial reservoirs in the Green River, Wasatch, and North Horn Formations since 1970 (Smouse, 1993).
Datum for the cross section is sea level so that hydrocarbon source rocks and reservoir rocks could be integrated into the structural framework of the basin.

Lithologies shown at each drill hole are modified from American Stratigraphic Company sample descriptions and available mudlogs. Lithologies shown for surface sections on the south end of the cross section are modified from Cashion (1967). Oil yields, in gallons per ton (GPT), that were measured using the Fischer assay method are available for 7 of the19 drill holes. These samples were analyzed in the 1970s to evaluate the oil shale resources in the Uinta Basin, and were used in the recent assessment of the in-place oil shale resources in the basin (Johnson and others, 2010b). Other information on the cross section includes: (1) results from drill-stem tests and perforations, (2) mudweights used during drilling, and (3) and Rock-Eval and vitrinite reflectance $\left(\mathrm{R}_{\mathrm{o}}\right)$ analyses from Anders and others (1992). The goal of this study is to determine if the oil found in the Uteland Butte member and R-0 zone was derived locally from mature source rocks or migrated into the dolomite and shale reservoirs from deeper, more mature source rocks.

\section{Stratigraphic Subdivisions of the Green River Formation}

The Green River Formation of the Uinta and Piceance Basins was deposited in Eocene Lake Uinta, a large saline lake that formed when two much smaller freshwater lakes, located in each of the Piceance and Uinta Basins expanded during the Long Point transgression (Johnson, 1985) and merged into one lake. Lake Uinta increased in salinity through time, ultimately precipitating large quantities of nahcolite $\left(\mathrm{NaHCO}_{3}\right)$ and halite $(\mathrm{NaCl})$. The Uteland Butte member of the Green River Formation was deposited in the earlier freshwater lake, whereas the $\mathrm{R}-0$ zone was the first oil shale zone deposited in the newly, expanded and increasingly saline Lake Uinta (figs. 2, 4). 


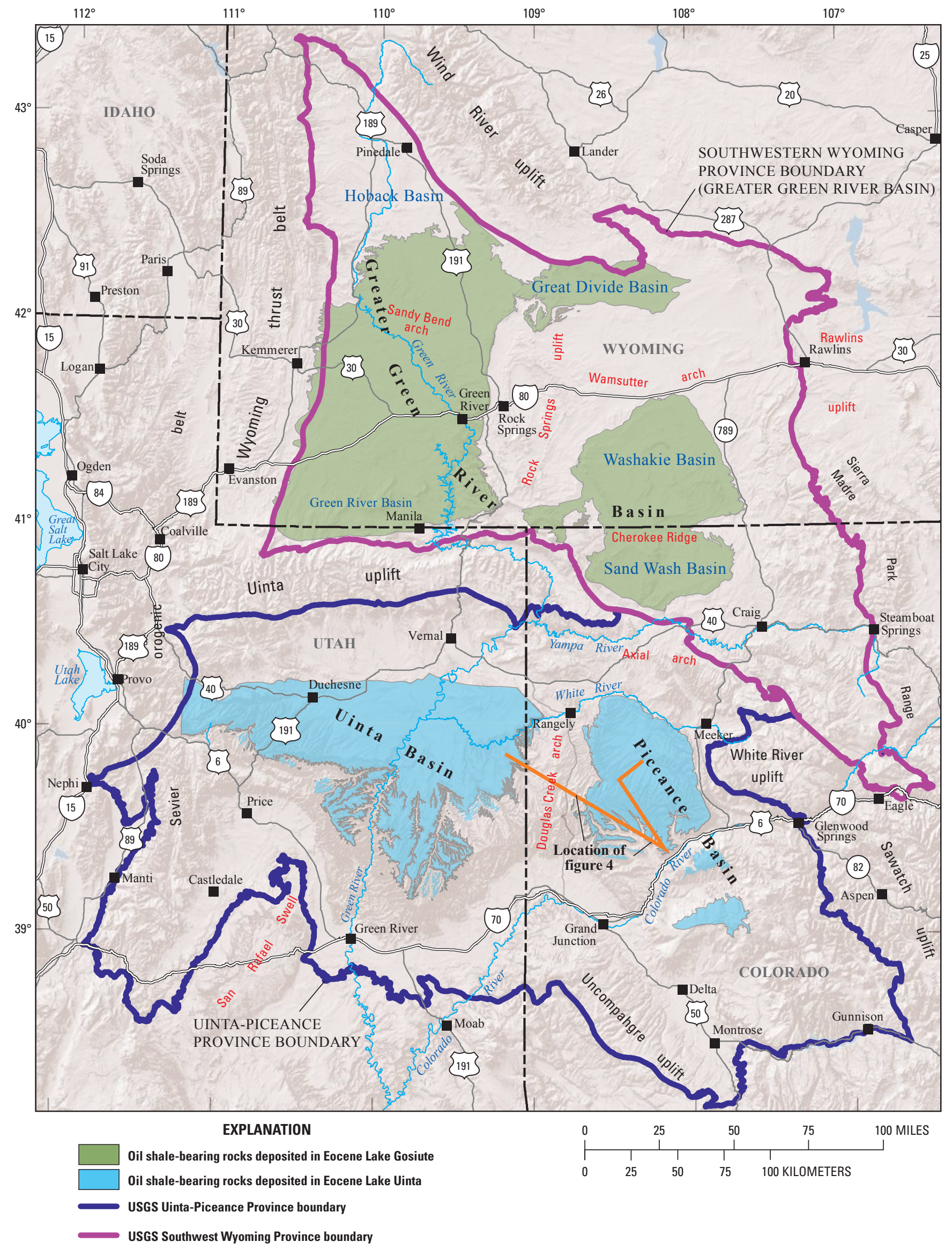


Figure 1 (Previous page). Map showing extent of Uinta, Piceance, and Greater Green River Basins, and the approximate extent of oil shale in the Green River Formation. Sub-basins in the Greater Green River Basin are labeled in blue. Major uplifts are labeled in black, and minor structural arches are labeled in red. Extent of the Uinta and Piceance Basins (dark blue) is the same as the Uinta-Piceance Province boundary (U.S. Geological Survey Uinta-Piceance Assessment Team, 2003). Extent of the Greater Green River Basin (magenta) is the same as the Southwest Wyoming Province boundary (U.S. Geological Survey Southwestern Wyoming Province Assessment Team, 2005). For the extent of oil shale in the Piceance Basin, the base of the Parachute Creek Member of the Green River Formation as mapped by Tweto (1979) was used for all but the northwest part of the basin where the base of the lower member of the Green River Formation is used. For the extent of oil shale in the eastern part of the Uinta Basin, the base of the Parachute Creek Member, as mapped by Cashion (1973) and Rowley and others (1985), was used. In the western part of the Uinta Basin, the top of the informal Mahogany bed of the Green River Formation, as mapped by Witkind (1995), was used. In the northern part of the Uinta Basin, only the area where oil shale is at a depth of 6,000 $\mathrm{ft}$ or less is shown; this area was outlined by using a structure contour map of the top of the Mahogany oil shale bed compiled by Johnson and Roberts (2003). For the Sand Wash, Washakie, Great Divide Basins, and southeastern part of the Green River Basin, the base of the Tipton Shale Member of the Green River Formation as mapped by Tweto (1979) and Love and Christiansen (1985) was used to show extent of oil shale. For the western part of the Green River Basin, the base of the Wilkins Peak Member of the Green River Formation, and for the northern part of the Green River Basin, the base of the Laney Shale Member of the Green River Formation as mapped by Love and Christiansen (1985) were used.

Lake Uinta remained a single lake across both basins and the intervening Douglas Creek arch throughout most of its history, and as a result most stratigraphic units can be recognized in both basins (figs. 2, 4). Formal member subdivisions of the Green River Formation recognized in the Piceance Basin and eastern part of the Uinta Basin are the Garden Gulch, Parachute Creek, and Douglas Creek Members (figs. 2, 4). These units are difficult to trace in the western part of Uinta Basin where informal names are generally applied to subdivisions of the Green River Formation. Several informal nomenclature schemes have been used to subdivide the Green River Formation in the western part of the Uinta Basin including: (1) basal member, delta facies, and shaly facies (Bradley, 1931); (2) delta facies, and barren and saline facies (Ryder and others, 1976); and (3) lower, middle, and upper members of the Green River Formation (Weiss and others, 1990). Saline Lake Uinta persisted much longer in the central and western parts of the Uinta Basin than elsewhere in the Uinta and Piceance Basins. The informal terms "saline facies of the Parachute Creek Member" (Ryder and others, 1976) and "upper saline facies of the Parachute Creek Member" (Dyni, 1996; Brownfield and others, 2010) are commonly applied to these younger lacustrine deposits, which contain a different saline mineral assemblage than the underlying Parachute Creek Member including eitelite $\left(\mathrm{Na}_{2} \mathrm{Mg}\left(\mathrm{CO}_{3}\right)_{2}\right)$, shortite $\left(\mathrm{Na}_{2} \mathrm{Ca}_{2}\left(\mathrm{CO}_{3}\right)_{3}\right)$, and wegscheiderite $\left(\mathrm{Na}_{5}\left(\mathrm{CO}_{3}\right)\left(\mathrm{HCO}_{3}\right)_{3}\right.$ (Bradley, 1931; Erickson, 1952; Milton and others, 1954; Dane, 1955; Milton, 1957; Dyni and others, 1985; Dyni, 1996).

The name Garden Gulch Member is generally applied in the eastern part of the Uinta Basin and throughout the Piceance Basin to the clay-rich (mainly illite) oil shale interval that was deposited in offshore areas early in the history of Lake Uinta (Bradley, 1931). The R-0 zone consists of the lowermost part of this illitic oil shale interval and the L-1 zone contains the uppermost part (fig. 4). The name Parachute Creek Member is applied in the eastern part of the Uinta Basin and the Piceance Basin to the dolomitic oil shale that overlies the Garden Gulch Member (Bradley, 1931). As with the term Garden Gulch Member, the term Parachute Creek Member is not generally used in the western part of the Uinta Basin. The name Douglas Creek Member is applied to marginal lacustrine rocks in both the eastern part of the Uinta Basin and the western part of the Piceance Basin. In the western part of the Uinta Basin, the informal term "black shale facies" is applied to the combined R-0 part of the Garden Gulch Member and the offshore oil shale interval of the underlying freshwater lake phase, known as the Uteland Butte member (fig. 2; Picard, 1959; Ryder and others, 1976). The name Uinta Formation is applied to a sequence of sandstones and siltstones containing abundant volcanic debris that interfinger with the upper part of the Green River Formation (fig. 2; Cashion and Donnell, 1974). The name Duchesne River Formation has been applied to the fluvial interval consisting of buff and gray sandstone, red and pink shale, and conglomerate that overlies the Uinta and Green River Formations along the axis of the Uinta Basin (Walton, 1944; Cashion and Brown, 1956).

Cashion and Donnell (1972) recognized that the entire oil shale interval in the Piceance Basin and eastern part of the Uinta Basin could be subdivided into a series of oil-rich zones (R-1 through R-6) and oil-lean zones (L-1 through L-5; fig. 4). Subsequently, the names R-0 and L-0 zones were applied to the lowest oil shale units in the Green River Formation as shown in fig. 4 (for example, see Johnson and others, 1988). The R-0 through L-1 zones are generally equivalent to the Garden Gulch Member, and the remaining overlying oil shale zones compose the Parachute Creek Member. Oil shale units above the R- 6 zone include - (in ascending order) B-groove, Mahogany zone, A-groove, bed 44 interval, and bed 76 interval. Although the oil shale interval above A-groove was not named by Cashion and Donnell (1972), they did trace several oil shale marker beds through that interval. Later, Donnell (2008) correlated 44 individual oil shale beds (not shown on fig. 4) above A-groove across much of the Piceance Basin and the eastern part of the Uinta Basin (fig. 4). All of 


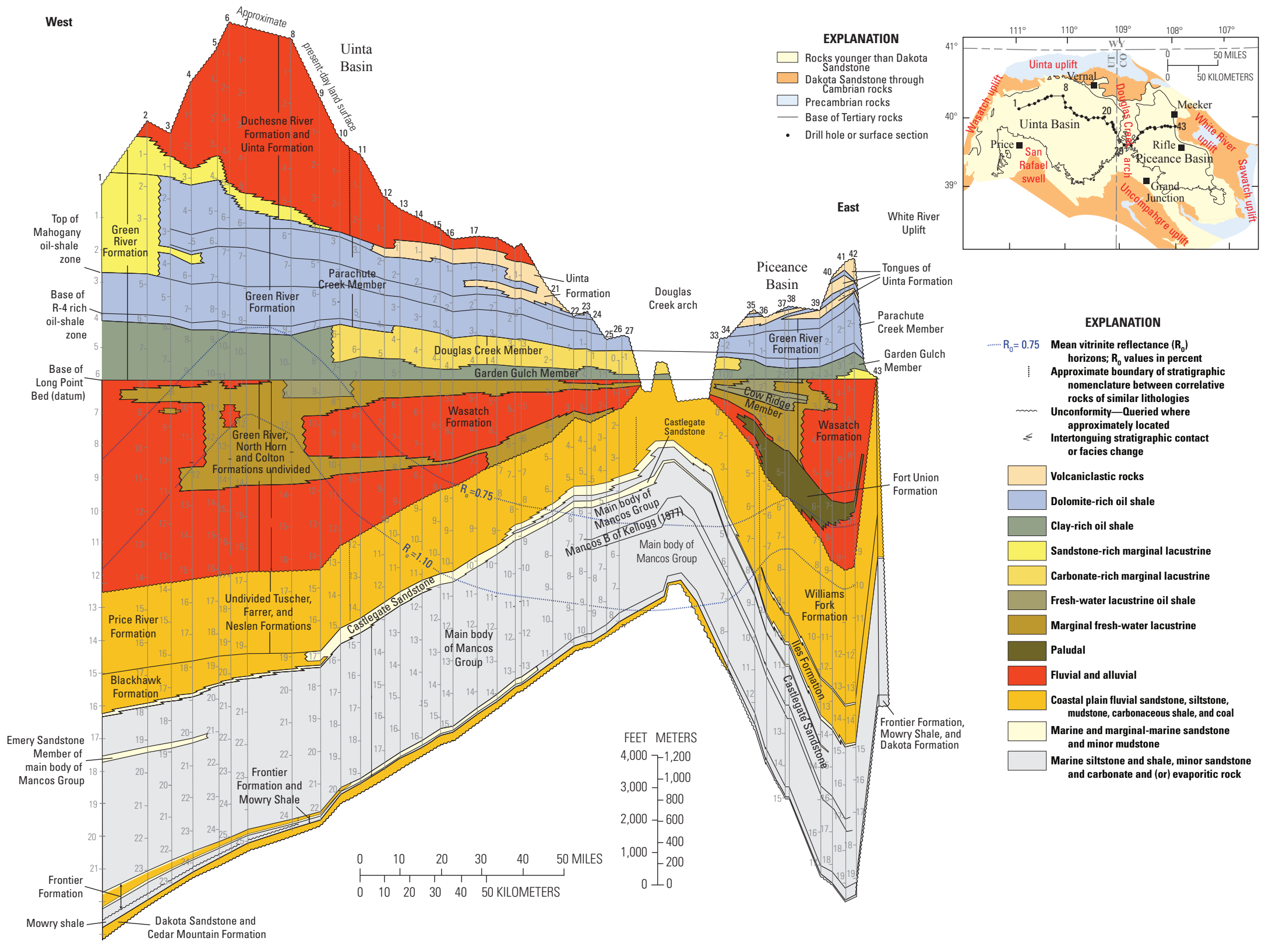

Figure 2. West-east cross section across the Uinta Basin, the Douglas Creek arch, and the Piceance Basin showing stratigraphic subdivisions, lithologies and variations in thermal maturity measured using vitrinite reflectance. Modified from Johnson and Roberts (2003). 


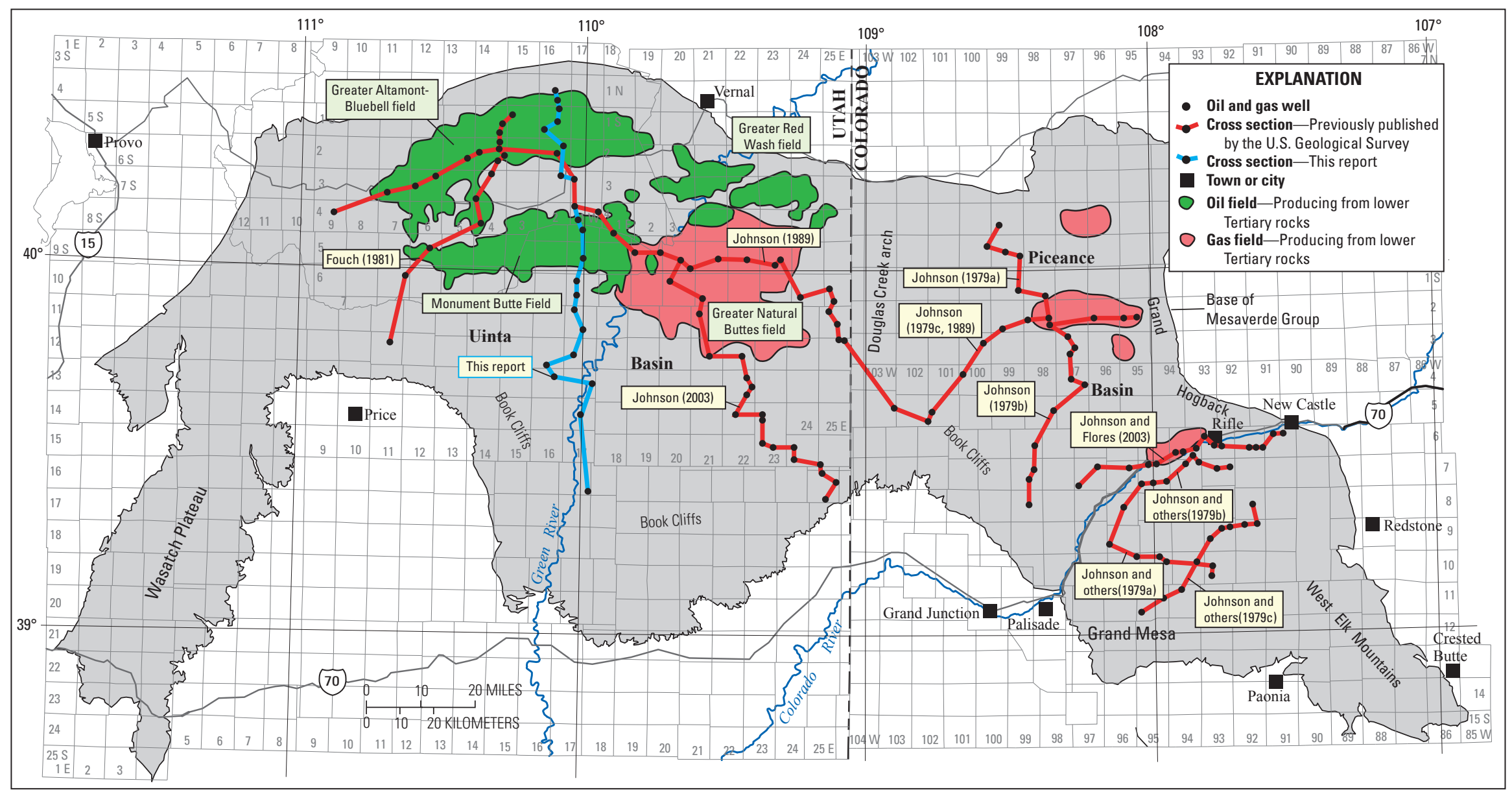

Figure 3. Index map showing detailed cross sections of upper Cretaceous and lower Tertiary rocks published by the U.S. Geological Survey in the Uinta and Piceance Basins (in red). North to south cross section of the Uinta Basin presented in this publication are shown in blue. 


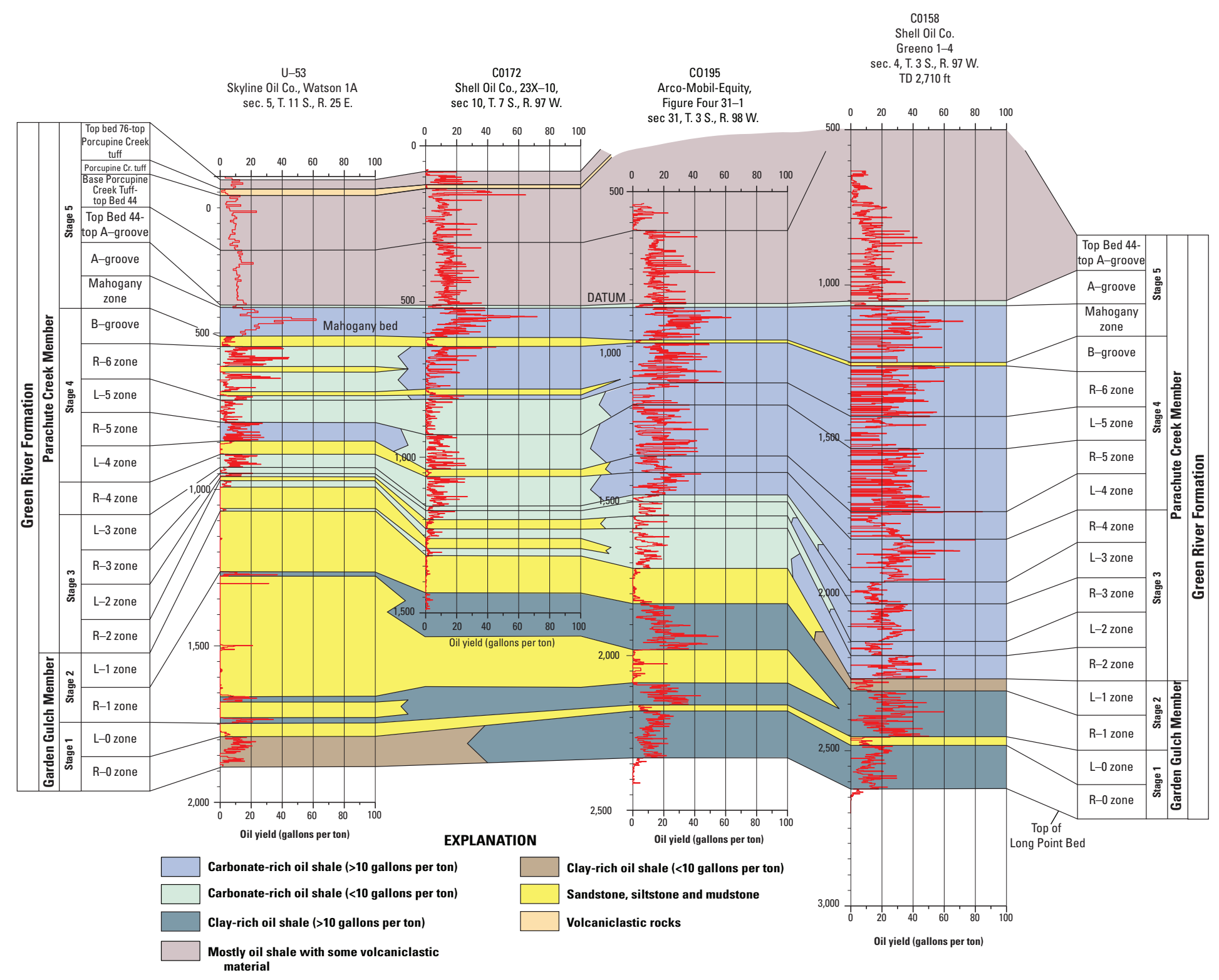

Figure 4. Cross section showing oil-yield histograms, members of the Eocene Green River Formation, correlation of rich- and lean-oil shale zones of Cashion and Donnell (1972), and stages in the evolution of Lake Uinta of Johnson (1985). The rich and lean zone from R-1 and above were originally defined by Cashion and Donnell (1972). The R-0 and L-0 zones were added later (for example, see Johnson and others, 1988). $\mathrm{U}-53$ is in the northeast corner of the Uinta Basin, C-158 is in the central part of the Piceance Basin, and core holes C0-172 and CO-195 are in the southeastern and central parts of the Piceance Basin, respectively. 
these oil shale beds and zones appear to correlate with timestratigraphic units that reflect changing rates of organic matter production and preservation that occurred simultaneously throughout Lake Uinta.

A major north-flowing drainage entered the Uinta Basin from the south near the south end of the cross section presented herein. The intertonguing relationships between marginal lacustrine rocks deposited in Lake Uinta and fluvial rocks deposited by this drainage were mapped in detail by Cashion (1967). The Douglas Creek Member was subdivided by Cashion (1967) into tongues A through F in this area, and many of these tongues are shown on the cross section (sheet 1). The extent of the deltaic facies related to this drainage over the course of several time periods are shown on a series of paleogeographic maps compiled by Johnson (1985). The sandy fluvial and marginal lacustrine facies appear to be confined to the upper part of the Wasatch Formation and Green River Formation suggesting that the influence of this north-flowing river on sedimentation in the basin increased with time.

\section{Variations in Thermal Maturity Using Rock-Eval and Vitrinite Reflectance}

Two different methods for measuring variations in thermal maturity were plotted on the cross section: (1) Rock-Eval pyrolysis (for a summary, see Tissot and Welte, 1984), and (2) vitrinite reflectance. In Rock-Eval pyrolysis, the sample is heated at $300{ }^{\circ} \mathrm{C}$ for $3-5$ minutes ( $\mathrm{min}$ ), at which point bitumen less than $\mathrm{C}_{33}$ and other volatile compounds that were originally present in the sample are released and measured $\left(\mathrm{S}_{1}\right.$ peak). The sample is then progressively heated to 550 $600{ }^{\circ} \mathrm{C}$, distilling heavy bitumen and releasing hydrocarbons generated by the cracking of kerogen $\left(\mathrm{S}_{2}\right.$ peak). The ratio of $\mathrm{S}_{1} / \mathrm{S}_{1}+\mathrm{S}_{2}$ is called the transformation ratio (production index). For any given kerogen type, the transformation ratio generally increases with increasing thermal maturity. Anders and Gerrild (1984) found that Type 1 organic matter in the Uinta Basin has a transformation ratio of greater than about 0.1, which indicated that the sample was mature with respect to oil generation. $\mathrm{T}_{\max }$ represents the temperature at which kerogen in the sample generates the most hydrocarbons, and it has been used as a thermal maturity indicator. However, $\mathrm{T}_{\max }$ for Type 1 kerogen such as those found in the Green River Formation appears to be relatively insensitive to increasing thermal maturity (Espitalie and others, 1986; Anders and others, 1992). The hydrogen to carbon ratio $(\mathrm{H} / \mathrm{C})$ is an important parameter in determining both the hydrocarbon generating potential of kerogen and thermal maturity (Waples, 1981; Hunt, 1996; Baskin, 1997). For Type 1 kerogen found in the Green River Formation in the Uinta Basin, Anders and others (1992, fig. 6) determined that there was a close relationship between $\mathrm{H} / \mathrm{C}$ ratio and thermal maturity as measured by vitrinite reflectance.

Vitrinite reflectance $\left(R_{o}\right)$ is a measurement of the percentage of light reflected off the vitrinite maceral at $\times 500$ magnification in oil immersion, and is commonly used as a measure of thermal maturity in organic-rich rocks. The vitrinite maceral is formed from woody plant tissue, whereas most kerogen found in the Green River Formation in the Uinta Basin is derived from algal material. Thus, studying variations in vitrinite reflectance is an indirect measurement of thermal maturity of the largely Type 1 kerogen in the Green River Formation of the Uinta Basin. For Type 1 kerogen, the onset of oil generation is thought to correspond to a vitrinite reflectance of about 0.75 percent, with oil generation complete at about $\mathrm{R}_{\mathrm{o}}$ of 1.2 to 1.3 percent (Baskin and Peters, 1992; Ruble and others, 2001).

Vitrinite reflectance results were published by Anders and others (1992) for four of the drill holes used on the cross section, and the information is plotted next to these drill holes (sheet 1). In addition, Anders and others (1992) published vitrinite reflectance measurements for surface samples throughout the basin. Two of these fall close to the axis of cross section and are projected onto the section from their approximate positions. Anders and others (1992) published $\mathrm{T}_{\max }$ values for five samples and $\mathrm{H} / \mathrm{C}$ ratios for two samples in the Sun Oil Co. 1 Daniel Uresk well along the line of section (well no. 14), and these values are plotted next to that well on the cross section (sheet 1).

The approximate positions of two vitrinite reflectance isoreflectance values are shown on the cross section: (1) $R_{0}$ 0.50 percent, and (2) $R_{o} 0.75$ percent, which is correlated to the onset of oil generation in Type 1 kerogen (sheet 1). The two isoreflectance lines dip markedly to the north, indicating that thermal maturities at any given elevation decrease northward and toward the axis of the basin adjacent to the Uinta Mountains. This was previously documented by Nuccio and others (1992) who suggested that this relationship could be in part explained by uplift of the margins of the basin bringing rocks with higher maturities to shallower levels while the trough of the basin was still subsiding and receiving sediments. The decrease in thermal gradients toward the axis of the Uinta Basin, noted by Chapman and others (1984) and Anders and others (1992), also probably played a role. These low thermal gradients near the basin axis are thought to be the result of cold meteoric water percolating into faults along the basin's north margin and heat being carried away by the thick, highly conductive Precambrian Uinta Mountain quartzite that was brought in contact with basin sediments by faulting (Chapman and others, 1984; Anders and others, 1992). The isoreflectance lines in the cross section are shown to abruptly bend upward over Monument Butte field to accommodate the comparatively high $\mathrm{R}_{\mathrm{o}}$ value of 0.55 percent obtained from a surface sample over that field. The suggestion that thermal maturities are atypically elevated over Monument Butte field is based on a single surface sample located $5,000-6,000 \mathrm{ft}$ above the producing interval at that site is tenuous at best.

A detailed vitrinite reflectance and Rock-Eval analysis of the Daniel Uresk well about 2-3 miles downdip from Monument Butte Oil Field (well number 14, sheet 1) was published by Anders and others (1992). Vitrinite reflectance values 
increase from 0.54 percent at a depth of $5,035 \mathrm{ft}$, located significantly above the productive Uteland Butte interval to 0.94 percent at $11,075 \mathrm{ft}$ in the lower part of the Wasatch Formation, which is significantly below the productive interval (sheet 1). An $\mathrm{R}_{\mathrm{o}}$ of 0.67 percent, or somewhat lower than the onset of hydrocarbon generation at $\mathrm{R}_{\mathrm{o}} 0.75$ percent, was obtained from the Uteland Butte member at a depth of $7,805 \mathrm{ft} . \mathrm{T}_{\max }$ values vary irregularly from 446 to $451^{\circ} \mathrm{C}$ throughout the well (sheet 1), supporting the idea that $\mathrm{T}_{\max }$ is an unreliable measure of thermal maturity for Type 1 kerogen. Hydrogen to carbon ratios $(\mathrm{H} / \mathrm{C})$ decrease with increasing depth from 1.33 at $5,035 \mathrm{ft}$, in the $\mathrm{R}-5$ oil shale zone $\left(\mathrm{R}_{\mathrm{o}}\right.$ 0.54 percent), to 1.18 in the Uteland Butte member at $7,805 \mathrm{ft}$ $\left(\mathrm{R}_{\mathrm{o}} 0.67\right.$ percent; sheet 1$)$. Transformation ratios $\left(\mathrm{S}_{1} / \mathrm{S}_{1}+\mathrm{S}_{2}\right)$ increase with depth from a minimum of 0.07 percent at $5,035 \mathrm{ft}$ to a maximum of 0.43 in the middle of the Uteland Butte member, and then decrease to a low of 0.07 percent below Uteland Butte at a depth of 11,075 ft (sheet 1).

A vitrinite reflectance of 0.67 percent at $7,805 \mathrm{ft}$ of the Uteland Butte member in the Daniel Uresk well indicates that the member is immature for oil generation. The unusually high production index of 0.43 for the Uteland Butte member in that well was attributed by Anders and Gerrild (1984, p. 520) to migrated hydrocarbons. The $\mathrm{H} / \mathrm{C}$ ratio of 1.18 indicates that the Uteland Butte member ranges from immature to marginally mature. Thus, thermal maturities must increase markedly between the Daniel Uresk well and the updip Monument Butte field for the oil in that field to have been generated in situ suggesting that the oil produced from that field migrated from more thermally mature source rocks elsewhere in the basin.

\section{Fischer Assay Analysis}

The Fischer assay method is a standardized laboratory test for determining the oil yield from oil shale, and has been almost universally used to determine oil yields for Green River Formation oil shales (Stanfield and Frost, 1949; American Society for Testing Materials, 1984). It is a much simpler, less rigorous analytical procedure than Rock-Eval. The Fischer assay standard method consists of heating a crushed and sieved (-8 mesh (2.38 millimeter mesh)) 100 gram sample in a small aluminum retort to $500{ }^{\circ} \mathrm{C}$ at a rate of $12{ }^{\circ} \mathrm{C} / \mathrm{min}$ and then held at that temperature for $40 \mathrm{~min}$. The volatile vapors of shale oil, gas, and water pass through a condenser cooled with ice water (about $5{ }^{\circ} \mathrm{C}$ ) and are collected in a graduated centrifuge tube. The oil and water are then separated by centrifugation and weighed. The quantities reported in the original sample are the weight percentages of shale oil, water, shale residue (containing carbon char), and "gas plus loss" (noncondensable gas yield). The specific gravity of the shale oil is measured and used to calculate the oil yield in GPT.

The Fischer assay method does not determine the total amount of hydrocarbons in an oil shale sample nor does it measure the amount or composition of the gases released during the heating of the sample. These gases - chiefly light hydrocarbons, hydrogen, and carbon dioxide - are reported as the "gas plus loss." In addition, it does not distinguish between hydrocarbons originally present in the sample ( $\mathrm{S}_{1}$ peak of Rock-Eval analysis) and hydrocarbons generated from kerogen during pyrolysis ( $\mathrm{S}_{2}$ peak).

Seven of the drill holes had oil yield analyses in GPT based on the Fischer assay method. During the 1960s and 1970s, the U.S. Bureau of Mines ran Fischer assay analysis on cuttings from a large number of drill holes in the Uinta Basin to evaluate the oil shale resources in the Uinta Basin. These analyses were used in the recent reassessment of oil shale resources in the Uinta Basin by Johnson and others (2010b). The original Fischer assay analysis for all drill holes in the Uinta Basin can also be accessed in that publication. Histograms showing variations in GPT of oil generated by Fischer assay for these seven drill holes are shown in sheet 1 . Results indicate that productive intervals in the lower part of the Green River Formation at Monument Butte field contain significant quantities of kerogen and oil, however, only the Mahogany zone averages more than 10 GPT. The Mahogany zone is probably immature for hydrocarbon generation along the axis of section and has not been a target for hydrocarbon exploration.

\section{Pressure Gradients}

Pressure gradients, determined from the maximum recorded shut-in pressures during drill-stem tests are listed in the table of drill hole information on sheet 1 and plotted at their proper depth next to the drill holes on the cross section. Pressure gradients are calculated by dividing the maximum shut in pressure at the depth of the base of the drill-stem test. A normal pressure gradient in a reservoir where saline water is the pressurizing fluid is about 0.43 pounds per square inch per foot (psi/ft). Pressure gradients that are as high as $0.83 \mathrm{psi} / \mathrm{ft}$ occur in the Altamont-Bluebell field. These high pressure gradients have been documented by many workers in the past (for example, see Lucas and Drexler, 1976). Pressure gradients of as high as $0.51 \mathrm{psi} / \mathrm{ft}$ were recorded in the productive interval at the Monument Butte field indicating moderately overpressured conditions.

\section{Discussion}

This paper assembles much of the published stratigraphic, lithologic, thermal maturity, and geochemistry information for a single axis of cross section in the Uinta Basin in an attempt to better understand the recent oil production from low permeability dolomite, and tight shale reservoirs in the Uteland Butte and R-0 intervals. The information presented here, however, is from near the Monument Butte field, but not from within the field itself. Based on this information, it appears that thermal 
maturities are too low within the field to have generated significant quantities of oil, suggesting that the oil produced from the field migrated from more thermally mature source rocks elsewhere in the basin. However, thermal gradients appear to be somewhat higher in Monument Butte field than at the nearest well outside the field with geochemistry downdip from the field, and it is possible that thermal maturities within the field are within the oil window. Geochemical and thermal maturity information from within Monument Butte Oil Field is needed to better understand this developing shale oil play.

\section{References Cited}

American Society for Testing Materials (ASTM), 1984, Designation D 388-80, Standard test method for oil from oil shale: Annual Book of ASTM Standards, 1984, p. 513-525.

Anders, D.E, and Gerrild, P.M., 1984, Hydrocarbon generation in lacustrine rocks of Tertiary age, Uinta Basin, UtahOrganic carbon, pyrolysis yield, and light hydrocarbons, in Woodward, Jane, Meissner, F.F., and Clayton, J.L., eds., Hydrocarbon Source Rocks of the Greater Rocky Mountain Region, Rocky Mountain Association of Geologists Guidebook: Denver, Colo., Rocky Mountain Association of Geologists, p. 513-524.

Anders, D.E., Palacas, J.G., and Johnson, R.C., 1992, Thermal maturity of rocks and hydrocarbon deposits, Uinta Basin, Utah, in Fouch, T. D., Nuccio, V. F., and Chidsey, T. C. Jr., eds., Hydrocarbon and Mineral Resources of the Uinta Basin, Utah and Colorado, Utah Geological Association Guidebook 20: Salt Lake City, Utah Geological Association, p. 53-76.

Baskin, D.K., 1997, Atomic H/C ratio of kerogen as an estimate of thermal maturity and organic matter conversion: American Association of Petroleum Geologists Bulletin, v. 81, no. 9 , p. $1437-1450$.

Baskin, D.K., and K.E. Peters, 1992, Early generation characteristics of a sulfur-rich Monterey kerogen: American Association of Petroleum Geologists Bulletin, v. 76, p. 1-13.

Bradley, W.H., 1931, Origin and microfossils of the oil shale of the Green River Formation of Colorado and Utah: U.S. Geological Survey Professional Paper 168, 58 p.

Brownfield, M.E., Johnson, R.C., and Dyni, J.R., 2010, Sodium carbonate resources of the Eocene Green River Formation, Uinta Basin, Utah and Colorado-Oil Shale Resources of the Uinta Basin, Utah and Colorado, chap. 2 of U.S. Geological Survey Oil Shale Assessment Team, eds., Oil shale resources of the Uinta Basin, Utah and Colorado: U.S. Geological Survey Digital Data Series 69-BB, 13 p.
Cashion, W.B., 1967, Geology and fuel resources of the Green River Formation southeastern Uinta Basin Utah and Colorado: U.S. Geological Survey Professional Paper 548, 48 p.

Cashion, W.B., 1973, Geologic and structure map of the Grand Junction quadrangle, Colorado and Utah: U.S. Geological Survey Miscellaneous Investigations Series Map I-736, scale 1:250,000.

Cashion, W.B., and Brown, J.H., Jr., 1956, Geology of the Bonanza-Dragon oil-shale area, Uintah County, Utah, and Rio Blanco County, Colorado: U.S. Geological Survey Oil and Gas Investigations Map OM-153, scale: 1:62,500.

Cashion, W.B., and Donnell, J.R., 1972, Chart showing correlation of selected key units in the organic-rich sequence of the Green River Formation, Piceance Creek Basin, Colorado, and Uinta Basin, Utah: U.S. Geological Survey Oil and Gas Investigations Chart OC-65.

Cashion, W.B., and Donnell, J.R., 1974, Revision of nomenclature of the upper part of the Green River Formation, Piceance Creek Basin, Colorado, and eastern Uinta Basin, Utah: U.S. Geological Survey Bulletin 1394-G, 9 p.

Chapman, D.S., Keho, T.H., and Bauer, M.S. 1984, Heat flow in the Uinta Basin determined from bottom hole temperature (BHT) data: Geophysics, v. 49, p. 453-466.

Dane, C.H., 1955, Stratigraphic and facies relationships of the upper part of the Green River Formation and the lower part of the Uinta Formation in Duchesne, Uintah, and Wasatch Counties, Utah: U.S. Geological Survey Chart OC-52.

Donnell, J.R., 1953, Columnar section of rocks exposed between Rifle and DeBeque Canyon, Colorado, in Rocky Mountain Association of Petroleum Geologists Guidebook, Field conference in north-western Colorado: Rocky Mountain Association of Geologists, 1953, p. 14.

Donnell, J.R., 1997, Correlation of individual oil-shale beds in the upper part of the Green River Formation, Piceance Creek Basin, Colorado, and Uinta Basin, Utah: U.S. Geological Survey Open-File Report 97-714, 6 p.

Donnell, J.R., 2008, Intertonguing of the lower part of the Uinta Formation with the upper part of the Green River Formation in the Piceance Creek Basin during the late stages of Lake Uinta: U.S. Geological Survey Scientific Investigation Report 2008-5237, 25 p.

Donnell, J.R., and Blair, R.W., 1970, Resource appraisal of three rich oil-shale zones in the Green River Formation, Piceance Creek Basin, Colorado: Colorado School of Mines Quarterly, v. 65, p. 73-87.

Durham, L.S., 2013, Unconventional Uteland Butte sparks new Utah activity: American Association of Petroleum Geologists (AAPG) Explorer, June 2013. 
Dyni, J.R., 1996, Sodium carbonate resources of the Green River Formation: U.S. Geological Survey Open-File Report 96-729, $39 \mathrm{p}$.

Dyni, J.R., Milton, Charles, and Cashion, W.B., Jr., 1985, The saline facies of the upper part of the Green River Formation near Duchesne, Utah, in Picard, M.D., ed., Geology and Energy Resources, Uinta Basin of Utah: Salt Lake City, Utah Geological Association, p. 51-80.

Erickson, M.P., 1952, New locality of shortite: American Mineralogist, v. 37, p. 342-344.

Espitalie, J., Deroo, G., and Marquis, F., 1986, La pyrolyse Rock-Eval et ses applications: Revue de l' Institut Francais du Petrole, v. 41, p. 73-89. [In French.]

Fouch, T.D., 1981, Distribution of rock types, lithologic groups, and interpreted depositional environments for some lower Tertiary and Upper Cretaceous rocks from outcrops at Willow Creek-Indian Canyon through the subsurface of Duchesne and Altamont oil fields, southwest to northcentral parts of the Uinta Basin, Utah: U.S. Geological Survey Oil and Gas Investigations Map Chart OC-81.

Fouch, T.D., and Cashion, W.B., 1979, Distribution of rock types, lithologic groups, and depositional environments for some lower Tertiary and Upper and Lower Cretaceous, and Upper and Middle Jurassic rocks in the subsurface between Altamont oil field and San Arroyo gas field, north-central to southeastern Uinta Basin, Utah: U.S. Geological Survey Open-File Report 79-365.

Fouch, T.D., Nuccio, V.F., Osmond, J.C., MacMillan, Logan, Cashion, W.B., and Wandrey, C.J., 1992, Oil and gas in Uppermost Cretaceous and Tertiary rock, Uinta Basin Utah, in Fouch, T.D., Nuccio, V.F., and Chidsey, T.C., Jr., eds, Hydrocarbon and Mineral Resources of the Uinta Basin, Utah and Colorado, Utah Geological Association Guidebook 20: Salt Lake City, Utah Geological Association, p. $9-47$.

Francyzk, K.J., Pitman, J.K., and Nichols, D.J., 1990, Sedimentology, mineralogy, palynology, and depositional history of some uppermost Cretaceous and lowermost Tertiary rocks along the Book and Roan Cliffs, east of the Green River: U.S. Geological Survey Bulletin 1787-N, 27 p.

Hunt, J.M., 1996, Petroleum geochemistry and geology (2nd ed.): San Francisco, Freeman Press, 743 p.

Johnson, R.C., 1979, Cross section A-A' of Upper Cretaceous and lower Tertiary rocks, northern Piceance Creek Basin, Colorado: U.S. Geological Survey Miscellaneous Field Investigations Map MF-1129A.
Johnson, R.C., 1979, Cross section B-B' of Upper Cretaceous and lower Tertiary rocks, northern Piceance Creek Basin, Colorado: U.S. Geological Survey Miscellaneous Field Investigations Map MF-1129B.

Johnson, R.C., 1979, Cross section C-C' of Upper Cretaceous and lower Tertiary rocks, northern Piceance Creek Basin, Colorado: U.S Geological Survey Miscellaneous Field Investigations Map MF-1129C.

Johnson, R.C., 1985, Early Cenozoic history of the Uinta and Piceance Creek Basins, Utah and Colorado, with special reference to the development of Eocene Lake Uinta, in Flores, R.M., and Kaplan, S.S., eds., Cenozoic Paleogeography of the west-central United States, Rocky Mountain Paleography Symposium 3: The Rocky Mountain Section, Society of Economic Paleontologists and Mineralogists p. 247-276.

Johnson, R.C., 1989, Detailed cross section correlating the Upper Cretaceous and lower Tertiary rocks between the Uinta Basin of eastern Utah and western Colorado and the Piceance Basin of western Colorado: U.S. Geological Survey Miscellaneous Investigations Map I-1974.

Johnson, R.C., 2003, Northwest to southeast cross section of Cretaceous and lower Tertiary rocks across the eastern part of the Uinta Basin, Utah, chap. 11 of U.S. Geological Survey Uinta-Piceance Assessment Team, compilers, Petroleum systems and geologic assessment of oil and gas in the Uinta-Piceance Province, Utah and Colorado: U.S. Geological Survey Digital Data Series 69-B, 6 p.

Johnson, R.C., 2012, The systematic geologic mapping program and a quadrangle-by-quadrangle analysis of the timestratigraphic relations within the oil shale-bearing rocks of the Piceance Basin, western Colorado: U.S. Geological Survey Scientific Investigations Report 2010-5041, 28 p. [Also available at $h t t p: / / p u b s . u s g s . g o v / s i r / 2012 / 5041 /$.]

Johnson, R.C., and Flores, R.M., 2003, History of the Piceance Basin from Latest Cretaceous through early Eocene and the characterization of lower Tertiary sandstone reservoirs, in Peterson, K. M., Olson, T. M., and Anderson, D. S., eds., Piceance Basin 2003 Guidebook, Rocky Mountain Association of Geologists Guidebook: Denver, Rocky Mountain Association of Geologists, p. 21-61, 1 oversized plate.

Johnson, R.C., Granica, M.P., Dessenberger, N.C., 1979, Cross section A-A' of Upper Cretaceous and lower Tertiary rocks, southern Piceance Creek Basin, Colorado: U.S. Geological Survey Miscellaneous Field Investigations Map MF-1130A.

Johnson, R.C., Granica, M.P., Dessenberger, N.C., 1979, Cross section B-B' of Upper Cretaceous and lower Tertiary rocks, southern Piceance Creek Basin, Colorado: U.S. Geological Survey Miscellaneous Field Investigations Map MF-1130B. 
Johnson, R.C., Granica, M.P., and Dessenberger, N.C., 1979, Cross section C $-\mathrm{C}$ ' of Upper Cretaceous and lower Tertiary rocks, southern Piceance Creek Basin, Colorado: U.S. Geological Survey Miscellaneous Field Investigations Map MF-1130C.

Johnson, R.C., Mercier, T.J., Brownfield, M.E., and Self, J.G., 2010a, Assessment of in-place oil shale resources of the Eocene Green River Formation, Uinta Basin, Utah and Colorado-Oil Shale Resources of the Uinta Basin, Utah and Colorado, chap. 1 of U.S. Geological Survey oil Shale Assessment Team, eds., oil shale and nahcolite resources of the Piceance Basin, Colorado: U.S. Geological Survey Digital Data Series 69-BB, 153 p., http://pubs.usgs.gov/dds/ $d d s-069 / d d s-069-y /$.

Johnson, R.C., Mercier, T.J., Brownfield, M.E., and Self, J.G., 2010b, Assessment of in-place oil shale resources of the Eocene Green River Formation, Uinta Basin, Utah and Colorado-Oil Shale Resources of the Uinta Basin, Utah and Colorado, chap. 1 of U.S. Geological Survey Oil Shale Assessment Team eds., Oil shale resources of the Uinta Basin, Utah and Colorado: U.S. Geological Survey Digital Data Series 69-BB, 153 p., http://pubs.usgs.gov/dds/dds069/dds-069-bb/.

Johnson, R.C., Nichols, D.J., and Hanley, J.H., 1988, Stratigraphic sections of Lower Tertiary strata and charts showing palynomorph and mollusc assemblages, Douglas Creek arch area Colorado and Utah: U.S. Geological Survey Miscellaneous Field Investigations Map MF-1997.

Johnson, R.C., and Roberts, S.B., 2003, The Mesaverde total petroleum system, Uinta-Piceance province, Utah and Colorado, chap. 7 of U.S. Geological Survey Uinta-Piceance Assessment Team, eds., Petroleum systems and geologic assessment of oil and gas in the Uinta-Piceance Province, Utah and Colorado: U.S. Geological Survey Digital Data Series 69-B, 63 p.

Kellogg, H.E., 1977, Geology and petroleum of the Mancos B Formation Douglas Creek arch area Colorado and Utah, in Veal, H.K., ed., Exploration Frontiers of the Central and Southern Rockies, Rocky Mountain Association of Geologists Guidebook: Denver, Rocky Mountain Association of Geologists, p. 167-179.

Lomax, J.D., 1993, Monument Butte, in Hill, B.G., and Bereskin, S.R., eds., Oil and Gas fields of Utah: Utah Geological Association Publication 22, non-paginated.

Love, J.D., and Christiansen, A.C., 1985, Geologic Map of Wyoming: U.S Geological Survey, scale 1:500,000.

Lucas, P.T., and Drexler, J.M., 1976, Altamont-Bluebell—A major naturally fractured stratigraphic trap, American Association of Petroleum Geologists Memoir 24, North American Oil and Gas Fields: Denver, American Association of Petroleum Geologists, p. 121-135.
Milton, Charles, 1957, Authigenic minerals of the Green River Formation of the Uinta Basin, Utah, in Seal, O.G., ed., Guidebook to the Geology of the Uinta Basin, 8th Annual Field Conference: Intermountain Association of Petroleum Geologists, p. 136-143.

Milton, Charles, Axelrod, J.M., and Grimaldi, F.S., 1954, New minerals reedmergnerite $(\mathrm{Na} 2 \mathrm{O} \cdot \mathrm{B} 2 \mathrm{O} 3 \cdot 6 \mathrm{SiO} 2)$ and eitelite $(\mathrm{Na} 2 \mathrm{O} \cdot \mathrm{MgO} \cdot \mathrm{CO} 2)$ associated with leucosphenite, shortite, searlesite, and crocidolite in the Green River Formation, Utah [abs.]: Geological Society of America Bulletin, v. 65, p. $1286-1287$.

Nuccio, V.F., and Johnson, R.C., 1989, Variations in vitrinite reflectance for the Upper Cretaceous Mesaverde Formation, southeastern Piceance Basin, northwestern Colorado, and implications for burial history and potential hydrocarbon generation: U.S. Geological Survey Bulletin 1787-H, p. H1-H10, 1 pl.

Nuccio, V.F., Schmoker, J.W., and Fouch, T.D., 1992, Thermal maturity, porosity, and lithofacies relationships applied to gas generation and production in Cretaceous and Tertiary low-permeability (tight) sandstones, Uinta Basin, Utah, in Fouch, T.D., Nuccio, V.F., and Chidsey, T.C., Jr., eds, Hydrocarbon and Mineral Resources of the Uinta Basin, Utah and Colorado, Utah Geological Association Guidebook 20: Salt Lake City, Utah Geological Association, p. 77-93.

Osmond, J.C., 1992, Greater Natural Buttes gas field, Uintah County, Utah, in Fouch, T.D., Nuccio, V.F., and Chidsey, T.C., Jr., eds, Hydrocarbon and Mineral Resources of the Uinta Basin, Utah and Colorado, Utah Geological Association Guidebook 20: Salt Lake City, Utah Geological Association, p. 143-163.

Picard, M.D., 1959, Green River and lower Uinta Formations subsurface stratigraphy in western Uinta Basin, Utah, in Geology of the Wasatch and Uinta Mountains transition area, Intermountain Association of Petroleum Geologists Guidebook, 10th annual Field Conference: Intermountain Association of Geologists, p. 139-149.

Rice, D.D., Fouch, T.D., and Johnson, R.C., 1992, Influence of source rock type, thermal maturity, and migration on composition and distribution of natural gases, Uinta Bain, Utah, in Fouch, T.D., Nuccio, V.F., and Chidsey, T.C., Jr., eds., Hydrocarbon and Mineral Resources of the Uinta Basin, Utah and Colorado, Utah Geological Association Guidebook 20: Salt Lake City, Utah Geological Association, p. $95-109$.

Rowley, P.D., Hansen, W.R., Tweto, Ogden, and Carrara, P.E., 1985 , Geologic map of the Vernal $1^{\circ} \times 2^{\circ}$ quadrangle, Colorado, Utah, and Wyoming: U.S. Geological Survey Miscellaneous Investigations Map I-1526, scale: 1:250,000. 
Ruble, T.E., Lewan, M.D., and Philp, R.P., 2001, New insights on the Green River petroleum system in the Uinta Basin from hydrous pyrolysis experiments: American Association of Petroleum Geologist Bulletin, v. 85, no. 8, p. 1333-1371.

Ryder, R.T., Fouch, T.D., and Elison, J.H., 1976, Early Tertiary sedimentation in the western Uinta Basin, Utah: Geological Society of America Bulletin, v. 87, p. 496-512.

Smouse, DeForrest, 1993, Altamont-Bluebell, in Hill, B.G., and Bereskin, S.R., eds., Oil and Gas fields of Utah: Utah Geological Association Publication 22, non-paginated.

Stanfield, K.E., Frost, I.C., 1949, Method of assaying oil shale by a modified Fischer retort: U.S. Bureau of Mines Report of Investigations 4477, $13 \mathrm{p}$.

Tissot, B.P., and Welte, D.H., 1984, Petroleum Formation and Occurrence (2d ed.): Berlin, Springer-Verlag, 699 p.

Tweto, Ogden, 1979, Geologic map of Colorado: U.S. Geological Survey, available through the Colorado Geological Survey, scale 1:500,000. [Available at http://geosurveystore. state.co.us/p-819-geologic-map-of-colorado-1979.aspx.]

U.S. Geological Survey Southwestern Wyoming Province Assessment Team, 2005, The Southeastern Wyoming Province-Introduction to a geologic assessment of undiscovered oil and gas resources, chap. 2 of U.S. Geological Survey Southwestern Wyoming Province Assessment Team, eds., Petroleum systems and Geologic assessment of oil and gas in the southwestern Wyoming Province, Wyoming, Colorado and Utah: U.S. Geological Survey Digital Data Series 69-D, $34 \mathrm{p}$.

U.S. Geological Survey Uinta-Piceance Assessment Team, 2003, The Uinta-Piceance Province, introduction to a geologic assessment of undiscovered oil and gas resources: U.S. Geological Survey Digital Data Series 69-B, 27 p.

Waples, D.W., 1981, Organic geochemistry for exploration geologists: Minneapolis, Burgess Publishing, 151 p.

Walton, P.D., 1944, Geology of the Cretaceous of the Uinta Basin, Utah: Geological Society of America Bulletin, v. 55, no. 1, p. 97-99.

Weiss, P.W., Witkind, I.J., and Cashion, W.B., 1990, Geologic map of the Price $30^{\prime} \times 60^{\prime}$ quadrangle, Carbon, Duchesne, Uintah, Utah, and Wasatch Counties, Utah: U.S. Geological Survey Miscellaneous Investigations Map I-1981, scale $1: 100,000$.

Witkind, I.J., 1995, Geologic map of the Price $1^{\circ} \times 2^{\circ}$ quadrangle, Utah: U.S. Geological Survey Miscellaneous Investigations Series Map I-2462, scale: 1:250,000.
Publishing support provided by:

Denver Publishing Service Center

For more information concerning this publication, contact: Center Director, USGS Central Energy Resources Science Center Box 25046, Mail Stop 939

Denver, CO 80225

(303) 236-1647

Or visit the Central Energy Resources Science Center Web site at: http://energy.usgs.gov/ 
